\title{
Non-aureus staphylococci in fecal samples of dairy cows: First report and phenotypic and genotypic characterization
}

\author{
A. Wuytack, ${ }^{1}$ A. De Visscher, ${ }^{2}$ S. Piepers, ${ }^{1}$ F. Boyen, ${ }^{3}$ F. Haesebrouck, ${ }^{3}$ and S. De Vliegher ${ }^{1 *}$ \\ ${ }^{1} \mathrm{M}$-team and Mastitis and Milk Quality Research Unit, Department of Reproduction, Obstetrics, and Herd Health, Faculty of Veterinary Medicine, \\ Ghent University, 9820 Merelbeke, Belgium \\ ${ }^{2}$ Flanders Research Institute for Agriculture, Fisheries and Food (ILVO), Technology and Food Science, Agricultural Engineering, \\ Burg. Van Gansberghelaan 115 bus 1, 9820 Merelbeke, Belgium \\ ${ }^{3}$ Department of Pathology, Bacteriology, and Avian Diseases, Faculty of Veterinary Medicine, Ghent University, 9820 Merelbeke, Belgium
}

\section{ABSTRACT}

The aims of this study were to determine whether non-aureus staphylococci (NAS) are present in rectal feces of healthy dairy cows, and if so, to delineate species to which they belong and to study several phenotypic and genotypic traits as a first step toward determining the potential impact of fecal shedding of NAS on bovine udder health. Fecal samples were aseptically collected from the rectum of 25 randomly selected clinically healthy dairy cows in a commercial dairy herd using an automated milking system. Fecal NAS were isolated and then identified at the species level using transfer RNA-intergenic spacer PCR and sequencing of the $16 \mathrm{~S}$ rRNA housekeeping gene. Strain typing was performed using random amplification of polymorphic DNA (RAPD)-PCR. The antimicrobial resistance profiles, biofilm formation, and growth and inhibitory characteristics of all NAS isolates were evaluated. Half of the cows were shedding NAS, resulting in 31 NAS isolates belonging to 11 different species. The most prevalent species were Staphylococcus rostri $(23 \%$, $\mathrm{n}=7)$, Staphylococcus cohnii $(16 \%, \mathrm{n}=5)$, and Staphylococcus haemolyticus $(13 \%, \mathrm{n}=4)$ with all Staphylococcus agnetis, Staphylococcus chromogenes, and Staph. rostri isolates belonging to the same strain according to RAPD banding patterns. Acquired antimicrobial resistance was observed in 28 of the 31 NAS isolates, mainly due to $\beta$-lactamase production. Most of the isolates $(84 \%, \mathrm{n}=27)$ had a weak biofilm-forming potential, but only 2 contained the bap gene. The $i c a$ and aap genes were not detected in any of the isolates. In vitro growth of Staphylococcus aureus and Streptococcus dysgalactiae was inhibited by Staph. agnetis isolates, and Staph. chromogenes isolates were able to inhibit the growth of Strep. dysgalactiae and Streptococcus uberis.

Received March 21, 2019.

Accepted May 28, 2019.

*Corresponding author: Sarne.Devliegher@UGent.be
All fecal isolates were able to grow when oxygen and iron were limitedly available, mimicking the growth conditions in the mammary gland.

Key words: dairy cow, feces, mastitis, non-aureus staphylococci

\section{INTRODUCTION}

Mastitis is the most important and costly disease in dairy cows worldwide. Non-aureus staphylococci have become the predominant bacteria in cases of subclinical mastitis in well-managed dairy herds (Pitkälä et al., 2004; Piepers et al., 2007; Schukken et al., 2009). The heterogeneous group of NAS consists of more than 50 (sub)species and differences have been reported in ecology, epidemiology, impact on udder health, and the presence of virulence or protective traits (Vanderhaeghen et al., 2014, 2015; Nobrega et al., 2018). Staphylococcus epidermidis, Staphylococcus haemolyticus, Staphylococcus sciuri, and Staphylococcus xylosus tend to be more resistant to antimicrobials than Staphylococcus aureus (Waller et al., 2011; Kot et al., 2012). In general, NAS easily show multiresistance (Taponen and Pyörälä, 2009; Sampimon et al., 2011; Waller et al., 2011) and can act as a reservoir of antimicrobial resistance genes for other bacteria such as Staph. aureus (Leonard and Markey, 2008). Several NAS have the ability to cause persistent IMI, such as Staphylococcus chromogenes, Staph. epidermidis, Staph. haemolyticus, and Staphylococcus simulans (Mørk et al., 2012; Fry et al., 2014), with biofilm production being one of the potential associated mechanisms (Cucarella et al., 2004). Another probable virulence factor of NAS is the capacity to grow in an anaerobic, iron-depleted environment, reflecting the intramammary environment (Mayer et al., 1988; Komine et al., 2005). On the other hand, certain NAS isolates are able to inhibit the growth of mastitis causing pathogens such as Staph. aureus, Staph. epidermidis, Streptococcus dysgalactiae, and Streptococcus uberis (De Vliegher et al., 2004; Braem et al., 2014). 
Non-aureus staphylococci are present in different habitats, such as the cows' environment (Piessens et al., 2011), teat apices (Braem et al., 2013; De Visscher et al., 2016b), inguinal skin (Adkins et al., 2018a,b), and bulk milk (De Visscher et al., 2017), and as the cause of IMI (Piessens et al., 2011; Supré et al., 2011; De Visscher et al., 2016a). For species with an environmental epidemiology, such as Escherichia coli and Klebsiella spp., fecal shedding has been confirmed to be a source of environmental contamination (Smith et al., 2001; Munoz et al., 2006; Verbist et al., 2011). Environmental transmission via feces has also been proven for Streptococcus agalactiae in cattle (Jørgensen et al., 2016). The gastrointestinal tract as a possible habitat for NAS has never been explored.

The aims of this study were to investigate whether healthy dairy cows are shedding NAS in their feces, and if so, to describe the species-specific distribution and determine the phenotypic and genotypic characteristics of the isolates.

\section{MATERIALS AND METHODS}

\section{Herd, Cows, and Samples}

Samples were collected at the commercial dairy herd of Ghent University (Biocenter Agrivet, Melle, Belgium) milking with an automated milking system (DeLaval VMS1, Tumba, Sweden). The average herd size was 66 Holstein-Friesian cows with an average of 55 lactating cows during the sampling period (i.e., August 2014 to February 2015). In the latter period, the yearly average production per cow was $9,028 \mathrm{~kg}$ of milk and the geometric mean of the monthly bulk milk SCC was 216,000 cells/mL milk. The cows were housed in a freestall barn with rubber mats and slatted floors. The cubicles were cleaned at least twice daily and refilled with sawdust, and the alleys were scraped several times per day by a manure robot.

Fecal samples $(\mathrm{n}=55)$ were collected from 25 randomly selected clinically healthy Holstein-Friesian cows from August 2014 to February 2015. Ten cows were sampled once and the other 15 cows were sampled 3 times with an interval of $2 \mathrm{~d}$. Fecal samples were taken in a sterile manner by the use of double, sterile gloves reflecting a guarded sampling technique for uterine samples (Messier et al., 1984). The outer rectal glove (without the hand) was used as a protective sheath ensuring no bacteria from the perineum contaminated the inner rectal glove. After both gloves entered the rectum, only the inner glove moved forward to collect rectal feces. Both gloves were retracted once the inner glove was pulled back in its protective sheath. The samples were transported to the Mastitis and Milk Quality
Research Laboratory (Faculty of Veterinary Medicine, Ghent University, Merelbeke, Belgium).

\section{Bacterial Isolation and Identification}

Fecal samples $(1 \mathrm{~g})$ were diluted in $9 \mathrm{~mL}$ of $0.9 \%$ physiological salt solution $(9 \mathrm{~g} \mathrm{NaCl} / \mathrm{L}$, Eurovet, Bladel, the Netherlands). A 0.01-mL loop of the suspended sample was spread on a semiselective medium, mannitol salt agar (MSA, Chapman medium, Oxoid, Aalst, Belgium), for NAS recovery as described by De Visscher et al. (2013). All phenotypically different colonies $(\geq 1$ colony) were counted, picked up, and subcultured on blood agar (Columbia agar with $5 \%$ sheep blood, Oxoid) to obtain pure cultures. They were presumptively identified as NAS following the routine phenotypic procedures as described by the National Mastitis Council (Hogan et al., 1999). All potential NAS isolates were then stored at $-80^{\circ} \mathrm{C}$ until further analyses.

DNA was extracted according to Unal et al. (1992), with some modifications. In the final step $3 \mu \mathrm{L}$ of RNase (1 mg/mL, Roche, Mannheim, Germany) was added. The isolates were identified at the species level using transfer RNA-intergenic spacer PCR (Supré et al., 2009). If no identification could be obtained using that method, sequencing of the $16 \mathrm{~S}$ rRNA housekeeping gene was performed as described before (Supré et al., 2009).

Random amplification of polymorphic DNA (RAPD)-PCR was used for strain typing of the NAS species with $\geq 2$ isolates. The RAPD-PCR was performed as described by Piessens et al. (2012b), with some modifications. The amplified DNA fragments were separated on $1.5 \%$ (wt/vol) agarose gels, previously stained with Midori Green Advance (GC biotech, Alphen aan den Rijn, the Netherlands), at $120 \mathrm{~V}$ for 4 h. Isolates of the same NAS species were analyzed in the same PCR run. Images were imported in BioNumerics version 7.6.3 (Applied Maths, Sint-MartensLatem, Belgium). The images were analyzed following Adkins et al. (2017) using the Dice similarity coefficient and the unweighted pair group method with arithmetic mean. The optimization and position tolerance were set at 0.5 and $1.0 \%$, respectively. Two additional Staph. chromogenes strains, Staph. chromogenes IM and Staph. chromogenes TA (see below), were included in the RAPD-PCR runs as internal controls. Per species, RAPD types were assigned an arbitrary lowercase letter based on the clustering.

\section{Characterization}

The NAS isolates were further characterized including 3 well-studied NAS isolates in every experiment for 
comparison: 2 Staph. chromogenes strains and 1 Staph. fleurettii isolate. The first Staph. chromogenes strain (Staph. chromogenes IM) originated from a persistent IMI lasting over 11 mo in a multiparous cow (MAS 694; Piessens et al., 2011), whereas the second strain (Staph. chromogenes TA) was isolated from the teat apex of a dairy heifer (De Vliegher et al., 2004). The Staph. fleurettii isolate was collected from sawdust (Piessens et al., 2011). These 3 NAS isolates have been used in several studies in lactating heifers (Piccart et al., 2016), in mice (Breyne et al., 2015), and with cell cultures (Souza et al., 2016). They differ in in vivo bacterial growth, shedding, and stimulating host immune response (e.g., neutrophil influx, apoptosis of polymorphonuclear cells, proinflammatory response) and in in vitro adherence to and internalization of MAC-T cells.

Antimicrobial Susceptibility. Antimicrobial susceptibility was determined using the disk diffusion method of Bauer et al. (1966). Colonies from all NAS isolates were suspended in sterile saline $(0.85 \% \mathrm{NaCl}$, bioMérieux, Marcy-l'Étoile, France) until a turbidity equivalent of 0.5 McFarland was achieved. With a sterile cotton swab, the inoculum was streaked in 3 directions onto a Mueller-Hinton agar plate (Oxoid). The sensitivity of all NAS isolates was independently tested 2 times on 2 different days using the following antimicrobial disks: penicillin $\mathrm{G}(10 \mathrm{U})$, cefoxitin (30 $\mu \mathrm{g})$, oxacillin $(1 \mu \mathrm{g})$, tetracycline $(30 \mu \mathrm{g})$, erythromycin $(15 \mu \mathrm{g})$, and gentamicin $(10 \mu \mathrm{g})$ (Neo-Sensitabs, Rosco Diagnostica, Taastrup, Denmark). The zone diameters were measured after aerobic incubation at $35^{\circ} \mathrm{C}\left(33-35^{\circ} \mathrm{C}\right.$ for cefoxitin/oxacillin) and interpreted in accordance with CLSI zone diameter interpretive standards based on human-derived data for veterinary pathogens (CLSI, 2018a). $\beta$-Lactamase production in isolates with a penicillin inhibition zone diameter $\geq$ $29 \mathrm{~mm}$ was detected with the induced nitrocefin disk test and the penicillin zone-edge test (CLSI, 2018b). The quality control strains used for the disk diffusion method were Staph. aureus (ATCC 25923) and E. coli (ATCC 25922); for the induced nitrocefin disk test and the penicillin zone-edge test, the strains were Staph. aureus (ATCC 29213) and Staph. aureus (ATCC 25923).

Biofilm Formation. The capacity to produce biofilm was tested for all NAS isolates on 3 different days, in triplicate on each day, using a phenotypic biofilm assay as described by Piessens et al. (2012a). The absorbance was measured with a microtiter plate reader at a wavelength of $540 \mathrm{~nm}$ (HydroFlex, Tecan, Switzerland). The strong biofilm-producing Staph. epidermidis strain ATCC 35984 and the weak biofilm-producing Staph. epidermidis strain ATCC 12228 were used as positive and negative controls, respectively (Tremblay et al., 2013). In each plate, in addition to the positive $(\mathrm{n}=3)$ and negative control strain $(\mathrm{n}=3)$, a blank (tryptic soy broth $+2 \%$ glucose) was added in triplicate. An isolate was considered a weak biofilm producer if the arithmetic mean of the 3 absorbance values of this isolate, on that day, was higher than the mean of the 3 absorbance values plus 3 times the standard deviation (SD) of the blank wells. When the calculated mean absorbance value of the isolate was above the mean absorbance value plus 3 times the SD of the weak biofilm control, the isolate was classified as a moderate biofilm producer (Christensen et al., 1985).

Growth Inhibition of Major Mastitis Pathogens. The modified cross-streaking method was performed, as described by De Vliegher et al. (2004), to evaluate the inhibitory capacity of all NAS isolates against 4 major mastitis pathogens: Staph. aureus (ATCC 29213), Strep. uberis (ATCC 19436), Strep. dysgalactiae (ATCC 43078), and E. coli (ATCC 25922). Each NAS isolate was inoculated onto a Columbia agar with 5\% sheep blood (Oxoid) with a center streak. After incubation, the agar was carefully loosened and turned upside down in a new sterile petri dish. A 0.5 McFarland dilution of each particular major pathogen was plated on the bottom-up agar in 3 directions for full coverage. After incubation, the plates were examined for bacterial growth, and inhibition of the major pathogen within and adjacent to the central-streak zone of the NAS isolate under study was measured. The major pathogens were also tested against themselves as a negative control and Staph. chromogenes TA was considered to be a positive control (De Vliegher et al., 2004). Inhibition patterns were interpreted as described by De Vliegher et al. (2004).

Growth Characteristics. To investigate the growth characteristics of the different NAS isolates, the technique described by Le Maréchal et al. (2009) was used with some modifications. All isolates were cultured in 2 media: brain heart infusion broth (BHI, Oxoid) and RPMI-1640 medium (Life Technologies, Fisher Scientific, Merelbeke, Belgium) under both aerobic and anaerobic conditions. The RPMI medium was first depleted of iron by adding deferoxamine (deferoxamine mesylate salt, $0.15 \mathrm{~m} M$, Sigma-Aldrich, Overijse, Belgium). A serial bacterial dilution was made according to Baron et al. (2006), but with the use of square tryptic soy agar plates (36 squares on each plate, Oxoid). After a 24-h incubation, the number of colony-forming units (cfu/ $\mathrm{mL}$ ) was counted. The same process was repeated 2 times, $48 \mathrm{~h}$ and $72 \mathrm{~h}$ later. Staphylococcus chromogenes TA, a less udder-adapted strain, was used as a negative control, and Staph. chromogenes IM, a more udderadapted strain, was used as positive control.

PCR Assays. The presence of the $\beta$-lactamasecoding bla $Z$ gene was detected as described before by 
Table 1. Primers used for the genotypic characterization of fecal NAS

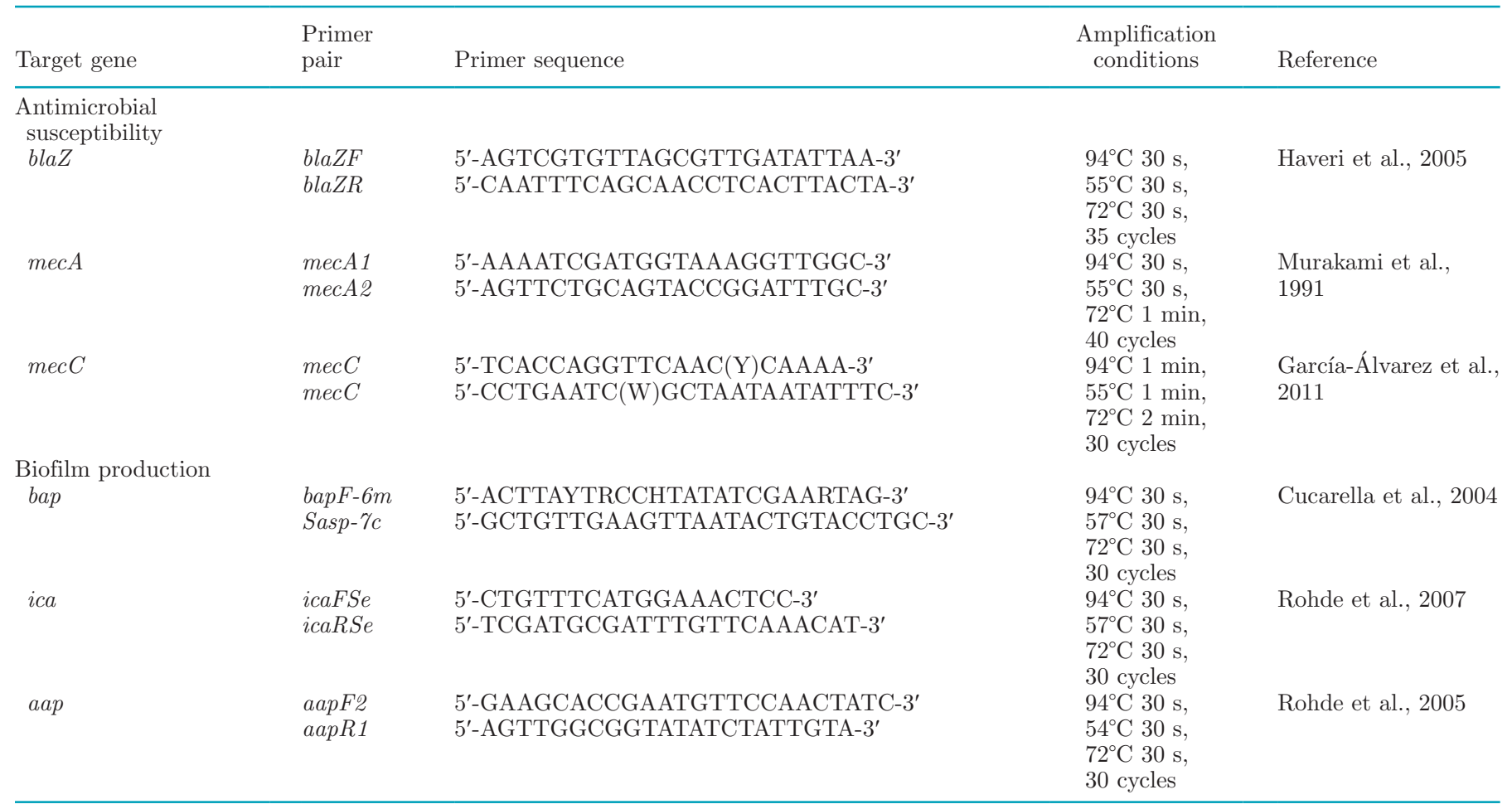

Haveri et al. (2005), with some modifications. The PCR mixture $(50 \mu \mathrm{L})$ contained $5 \mu \mathrm{L}$ of $10 \times$ Optimized DyNAzyme EXT buffer (Fisher Scientific) and $0.5 \mathrm{U}$ of DyNAzyme EXT DNA Polymerase (F-505L DyNAzyme EXT DNA Polymerase, Fisher Scientific) as buffer and DNA polymerase, respectively. The characteristics of the primers are shown in Table 1. The positive control in this study was Staph. aureus ATCC 29213.

The PCR assays of the methicillin-resistance genes mec $A$ and the mecA homolog $m e c A_{\mathrm{LGA} 251}$, also called mec $C$ (primers shown in Table 1) were executed as described by Piessens et al. (2012a) and García-Álvarez et al. (2011). Staphylococcus aureus ATCC 33591 and Staph. aureus LGA251 were used as positive controls for mecA and mec $C$, respectively.

The presence of biofilm-associated genes bap, ica, and aap was detected by PCR as described by Tremblay et al. (2013) (Table 1). Staphylococcus xylosus ATCC 29971 was used as a positive control for the bap gene and Staph. epidermidis ATCC 35984 for the aap and ica genes.

Analysis of the amplification fragments was performed by electrophoresis on $1.5 \%$ (wt/vol) agarose gels, previously stained with Midori Green Advance (GC Biotech). In each PCR run, a positive and a negative control (without DNA template) were included. Isolates with an equal amplicon size to the positive control were considered PCR positive for the particular gene under scrutiny.

\section{RESULTS}

\section{Bacterial Isolates}

All fecal samples $(\mathrm{n}=55)$ yielded growth on MSA. In total, 31 different isolates belonging to 11 different NAS species were identified (Table 2) with Staphylococcus rostri $(23 \%$ of all isolates, $\mathrm{n}=7$ ), Staphylococcus cohnii $(16 \%, \mathrm{n}=5)$, and Staph. haemolyticus (13\%, n $=4$ ) as the predominant species (Table 2).

More than half of the cows $(n=13$ out of 25$)$ were shedding NAS, with up to 3 different NAS species being found per fecal sample. The same species was isolated more than once in 4 out of the 55 fecal samples due to the presence of phenotypically different colonies on MSA for those particular species. The sampling of 15 cows was repeated twice with an interval of $2 \mathrm{~d}$, but none of the animals were shedding the same species in consecutive samplings. Only 1 cow harbored Staph. cohnii in the first and third fecal samples.

The 3 Staph. agnetis isolates, 2 Staph. chromogenes isolates, 6 out of 7 Staph. rostri isolates, 2 out of 3 Staphylococcus auricularis isolates, and 3 out of 5 Staph. cohnii isolates belonged to the same strain according to the RAPD fingerprints (Figure 1). The Staph. cohnii 
Table 2. Species distribution of NAS found in rectal feces of dairy cows

\begin{tabular}{lcccc}
\hline NAS isolate & $\begin{array}{c}\text { No. of } \\
\text { isolates }^{1}\end{array}$ & $\begin{array}{c}\text { \% of total } \\
\text { isolates }\end{array}$ & $\begin{array}{c}\text { No. of positive } \\
\text { cows }^{2}\end{array}$ & $\begin{array}{c}\% \text { of positive } \\
\text { cows }^{3}\end{array}$ \\
\hline Staph. rostri & 7 & 22.6 & 6 & 46 \\
Staph. cohnii & 5 & 16.2 & 4 & 31 \\
Staph. haemolyticus & 4 & 12.9 & 3 & 23 \\
Staph. agnetis & 3 & 9.7 & 1 & 8 \\
Staph. auricularis & 3 & 9.7 & 3 & 23 \\
Staph. equorum & 3 & 9.7 & 3 & 8 \\
Staph. chromogenes & 2 & 6.4 & 1 & 8 \\
Staph. epidermidis & 1 & 3.2 & 1 & 8 \\
Staph. hominis & 1 & 3.2 & 1 & 8 \\
Staph. kloosii & 1 & 3.2 & 13 & 100 \\
Staph. xylosus & 1 & 3.2 & & 8 \\
Total & 31 & 100 &
\end{tabular}

isolates recovered from the same cow at the first and third sampling also belonged to the same strain, while the second sample did not harbor Staph. cohnii. All Staphylococcus equorum and all Staph. haemolyticus isolates, on the other hand, belonged to different strains.

\section{Antimicrobial Susceptibility}

Based on the disk diffusion method and the nitrocefin and zone-edge test for $\beta$-lactamase production, phenotypic resistance to 1 or 2 antimicrobial agents was present in 18 fecal isolates (58\%; Table 3). Based on the 3 phenotypic tests for $\beta$-lactamase production, 17 isolates (1 out of 3 Staph. auricularis isolates, both Staph. chromogenes isolates, 4 out of 5 Staph. cohnii isolates, the Staph. epidermidis isolate, the Staph. kloosii isolate, all 7 Staph. rostri isolates, and the Staph. xylosus isolate) were resistant, as was Staph. chromogenes IM. All the Staph. cohnii isolates showed oxacillin resistance, even though only 3 of 5 isolates showed reduced cefoxitin inhibition zone diameters (Table 4). One Staph. equorum of 3 and the only Staph. xylosus isolate showed reduced inhibition zone diameters for tetracycline. One of 5 Staph. cohnii isolates and the Staph. epidermidis isolate showed reduced inhibition zone diameters for erythromycin. Both latter isolates were also $\beta$-lactamase positive. The results of the control strains were within the acceptable quality control ranges as provided by CLSI.

The blaZ gene, encoding $\beta$-lactamase production, was present in all the fecal isolates except for 1 of 3 Staph. agnetis isolates, 1 of 5 Staph. cohnii isolates, 1 out of 3 Staph. equorum isolates, and 1 out of 4 Staph. haemolyticus isolates. We also observed the blaZ gene in Staph. chromogenes IM, Staph. chromogenes TA, and Staph. fleurettii. Isolates with contrasting results for one of the phenotypic and genotypic methods to detect $\beta$-lactamase production are displayed in Table 5 .

None of the 31 fecal isolates carried the mecC gene. The Staph. fleurettii isolate originating from sawdust was the only isolate carrying the mecA gene. In contrast to the agar disk diffusion test with oxacillin, the Staph. fleurettii isolate tested sensitive using the agar disk diffusion method with cefoxitin (Table 4).

\section{Biofilm Formation}

All NAS isolates were capable of forming a biofilm except for the Staph. auricularis and Staph. kloosii isolates. The intensity of the biofilm-positive isolates differed somewhat. Of the 27 biofilm-producing NAS isolates (out of 31), 26 had a weak ability to produce biofilms and only 1 of 4 Staph. haemolyticus isolates showed a moderate biofilm-forming capacity. The 3 additional isolates showed a weak ability to form biofilms.

Among the biofilm-forming isolates, only 2 were bappositive: 1 Staph. equorum and 1 Staph. xylosus isolate. The $i c a$ and aap genes were not detected in any of the NAS isolates.

\section{Growth Inhibition of Major Pathogens}

All in vitro inhibition growth diameters of the fecal Staphylococcus isolates and the 3 additional strains used for comparison are presented in Table 6. Eight NAS isolates were able to inhibit the growth of Staph. aureus, Strep. uberis, Strep. dysgalactiae, or more than one of these species. One of 4 Staph. haemolyticus isolates showed inhibition of Strep. dysgalactiae, as did 2 of 5 Staph. cohnii isolates. The 3 Staph. agnetis isolates inhibited the growth of both Staph. aureus and Strep. dysgalactiae. The 2 fecal Staph. chromogenes isolates 


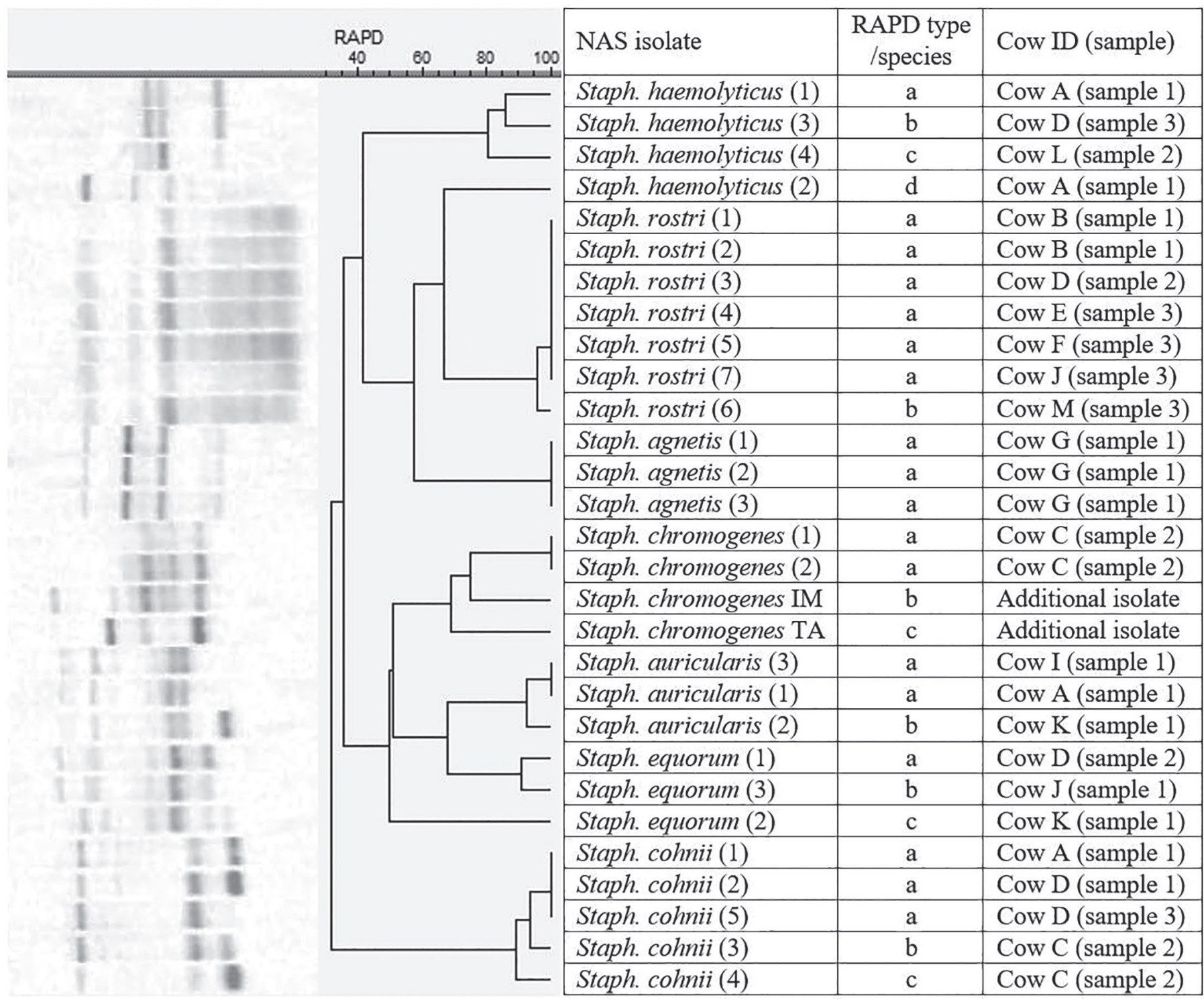

Figure 1. Dendrogram of the random amplification of polymorphic DNA (RAPD) fingerprints of 27 fecal NAS with $\geq 2$ isolates per species as well as 2 additional NAS strains used for comparison (Staphylococcus chromogenes IM and Staph. chromogenes TA). Per species, RAPD types were assigned an arbitrary lowercase letter based on the clustering. The 2 additional isolates, Staph. chromogenes IM and Staph. chromogenes TA, have been used in a number of studies in lactating heifers (Piccart et al., 2016), in mice (Breyne et al., 2015), and with cell cultures (Souza et al., 2016).

induced a zone of total growth inhibition against Strep. dysgalactiae and Strep. uberis. None of the isolates induced growth inhibition of $E$. coli. The other isolates showed no growth inhibition in the central-streak zone or had colonies that were smaller in the central part compared with those on the rest of the plate.

Staphylococcus chromogenes TA, used as a positive control, showed total growth inhibition of Staph. aureus and Strep. dysgalactiae and partial inhibition of Strep. uberis, as expected. Staphylococcus chromogenes IM and Staph. fleurettii induced a zone of partial inhibition against Strep. dysgalactiae and Strep. uberis.

\section{Growth Characteristics}

Figure 2 shows an overview of growth in different media for Staph. cohnii, Staph. equorum, Staph. haemolyticus, Staph. rostri, and the other NAS. Both BHI and RPMI with deferoxamine sustained growth under aerobic and anaerobic conditions for the fecal Staphylo- 
coccus isolates. However, the growth (expressed as log $(\mathrm{cfu} / \mathrm{mL})$ seemed higher in an iron-rich medium. The 3 Staph. equorum isolates especially showed a visibly lower growth under iron-deprived circumstances.

Staphylococcus chromogenes IM showed small differences of growth in different media. Staphylococcus chromogenes TA, contrarily, showed visibly reduced growth in an iron-deprived medium. In combination with anaerobic conditions, even no growth was detected for this specific isolate. The Staph. fleurettii isolate displayed better growth when iron was available in the environment.

\section{DISCUSSION}

To our knowledge, this study is the first to describe the presence and distribution of genotypically identified NAS species in fecal samples of dairy cows. Fecal shedding of NAS was already described for other animals and humans (Eastick et al., 1996; Slaughter et al., 2001; Vitali et al., 2014), yet not for cows. One study in South Africa revealed the presence of NAS in some samples of animal dung from chickens, pigs, and cattle, but it is not clear whether the fecal samples were taken in a sterile manner from the rectum rather than from the environment. Further, the results were listed as unspeciated staphylococcal isolates without reference to the animal source (Adegoke and Okoh, 2014).

Both so-called host-adapted species, such as Staph. chromogenes and Staph. epidermidis, and species with an environmental ecology, such as Staph. equorum, were isolated from fecal samples in this study. Strikingly, Staph. rostri was the most prevalent species, whereas it is rarely found in bovine milk, in contrast to dairy water buffaloes, in which Staph. rostri caused a third of NAS IMI in one study (Locatelli et al., 2013). In the study of De Visscher et al. (2017), Staph. rostri was found in a bulk milk sample of a dairy herd, yet the exact origin (cow versus environment) was undetermined. According to the current study findings, we hypothesize that Staph. rostri may act as an indicator of fecal contamination of bulk milk similar to E. coli (Ruusunen et al., 2013; Ntuli et al., 2016) although this possibility needs confirmation.

Non-aureus staphylococcal species such as Staph. chromogenes, Staph. cohnii, Staph. epidermidis, and Staph. xylosus that are frequently isolated from milk samples collected at parturition and throughout lactation were detected in rectal feces of dairy cows (Frey et al., 2013; Condas et al., 2017). We also isolated species more regularly found on teat apices such as Staph. chromogenes, Staph. cohnii, Staph. equorum, and Staph. haemolyticus (De Visscher et al., 2014, 2016b). We hypothesize that NAS shed via feces are capable of 
teat apex colonization and are causing IMI. A more extensive study with samples from the above-mentioned habitats and feces collected at the same time, relying on strain typing, is needed to confirm this hypothesis. However, other species often observed in milk samples or on teat apices, such as Staph. simulans (Braem et al., 2013; Bexiga et al., 2014) and Staphylococcus devriesei (De Visscher et al., 2016b), were not isolated from the fecal samples. This lack could be due to the small number of samples collected in our study, or it could suggest a habitat or herd specificity.

All Staph. agnetis, all Staph. chromogenes, and 6 of 7 Staph. rostri isolates belonged to the same strain according to the RAPD results, and similar phenotypic and genotypic traits were observed among all isolates of those species. The latter suggests that all 7 Staph. rostri isolates belonged to the same RAPD strain, which was confirmed with visual inspection of the banding patterns. Still, small differences in the position of the bands caused a dissimilarity observed by the BioNumerics software. We hypothesize that the Staph. rostri isolates in our study are adapted to the gastrointestinal tract system or contain a high genetic homogeneity as observed for Staph. chromogenes by Piessens et al. (2012b). Still, the samples were collected in only 1 herd, which potentially resulted in limited genetic diversity as well. Isolates from the same sample belonging to the same NAS species and displaying a similar strain type could as well be multiple colonies from the same clone although the colonies differed phenotypically. In comparison with the performed characterization tests, RAPD seems sufficient to differentiate strains of Staph. cohnii, Staph. equorum, and Staph. haemolyticus. This was in contrast to Staph. auricularis, for which the RAPD results were not in accordance with the presence of antimicrobial resistance genes. For specific species, the typeability of RAPD might be limited.
Penicillin resistance due to $\beta$-lactamase production, an antimicrobial component often used in Flemish dairy herds (Stevens et al., 2018), was the most common type of antimicrobial resistance in the fecal isolates, a finding that is in line with NAS isolated from bovine milk collected in other countries (Pitkälä et al., 2004; Sampimon et al., 2011; Waller et al., 2011). Similar to NAS originating from bovine milk samples, fecal NAS isolates seem to be more resistant than Staph. aureus (Kot et al., 2012).

The phenotypic resistance of fecal NAS isolates, according to the CLSI breakpoints based on humanderived data for veterinary pathogens, does not fully correspond with the presence of the antimicrobial resistance encoding genes blaZ, mecA, and mecC. For staphylococci, CLSI (2018a) recommends using the nitrocefin-based test or the zone-edge test of a penicillin disk diffusion test for the detection of $\beta$-lactamase resistance to sidestep this discrepancy. The oxacillin disk diffusion method for detecting mecA-mediated methicillin resistance in NAS (except for Staphylococcus pseudintermedius and Staphylococcus schleiferi) is not advised by CLSI (2018a). Still, we found a better agreement for Staph. fleurettii between the presence of mecA and the disk diffusion method for oxacillin than for cefoxitin (one of the recommended methods for this NAS species). Species-specific zone inhibition diameters/breakpoints for staphylococci, isolated from animals, are required to improve the sensitivity and specificity for a reliable detection of the presence of antimicrobial resistance in NAS originating from cowside sampling. Due to the low expression of methicillin resistance, different methods are recommended for the detection of methicillin resistance for Staph. aureus, Staphylococcus lugdunensis, Staph. pseudintermedius, Staph. schleiferi, and the other NAS as a group. As in other studies, species-specific methods or the com-

Table 4. Comparison of phenotypic and genotypic methods for the detection of methicillin resistance in isolates with contrasting results

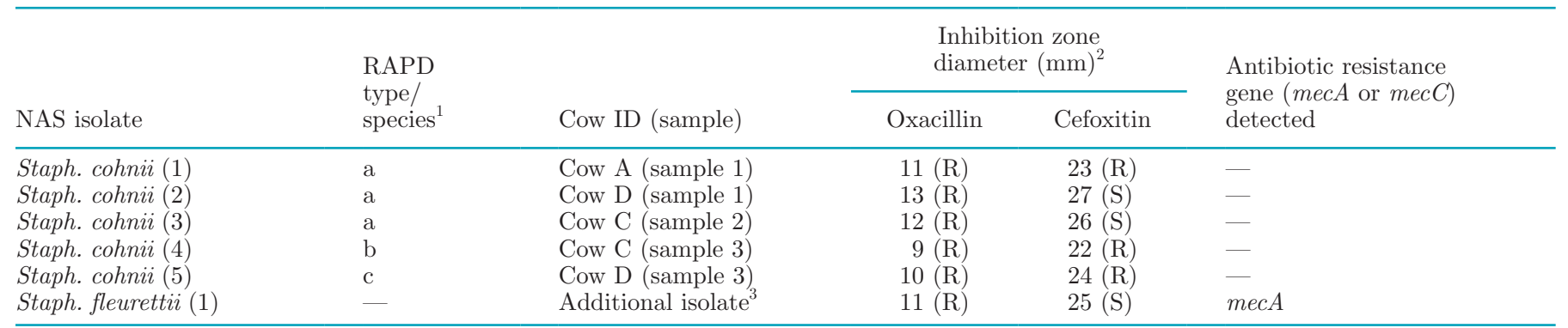

${ }^{1}$ Per species, random amplification of polymorphic DNA (RAPD) types were assigned an arbitrary lowercase letter based on the clustering.

${ }^{2}$ Zone inhibition diameters were interpreted according to the human-derived zone diameter interpretive standards for veterinary pathogens (CLSI, 2018a). The interpretations are given in parentheses $(\mathrm{R}=$ resistant, $\mathrm{S}=$ sensitive).

${ }^{3}$ Breyne et al. (2015), Piccart et al. (2016), Souza et al. (2016). 


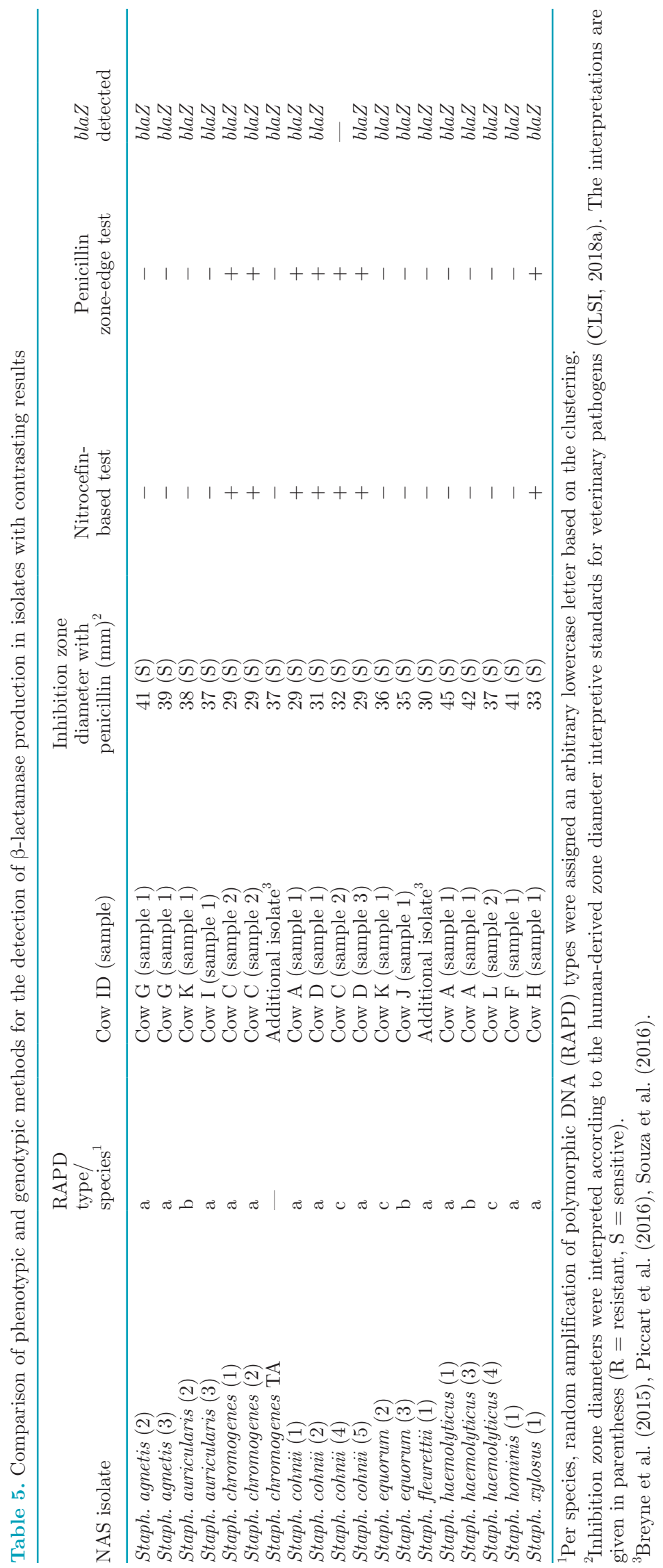




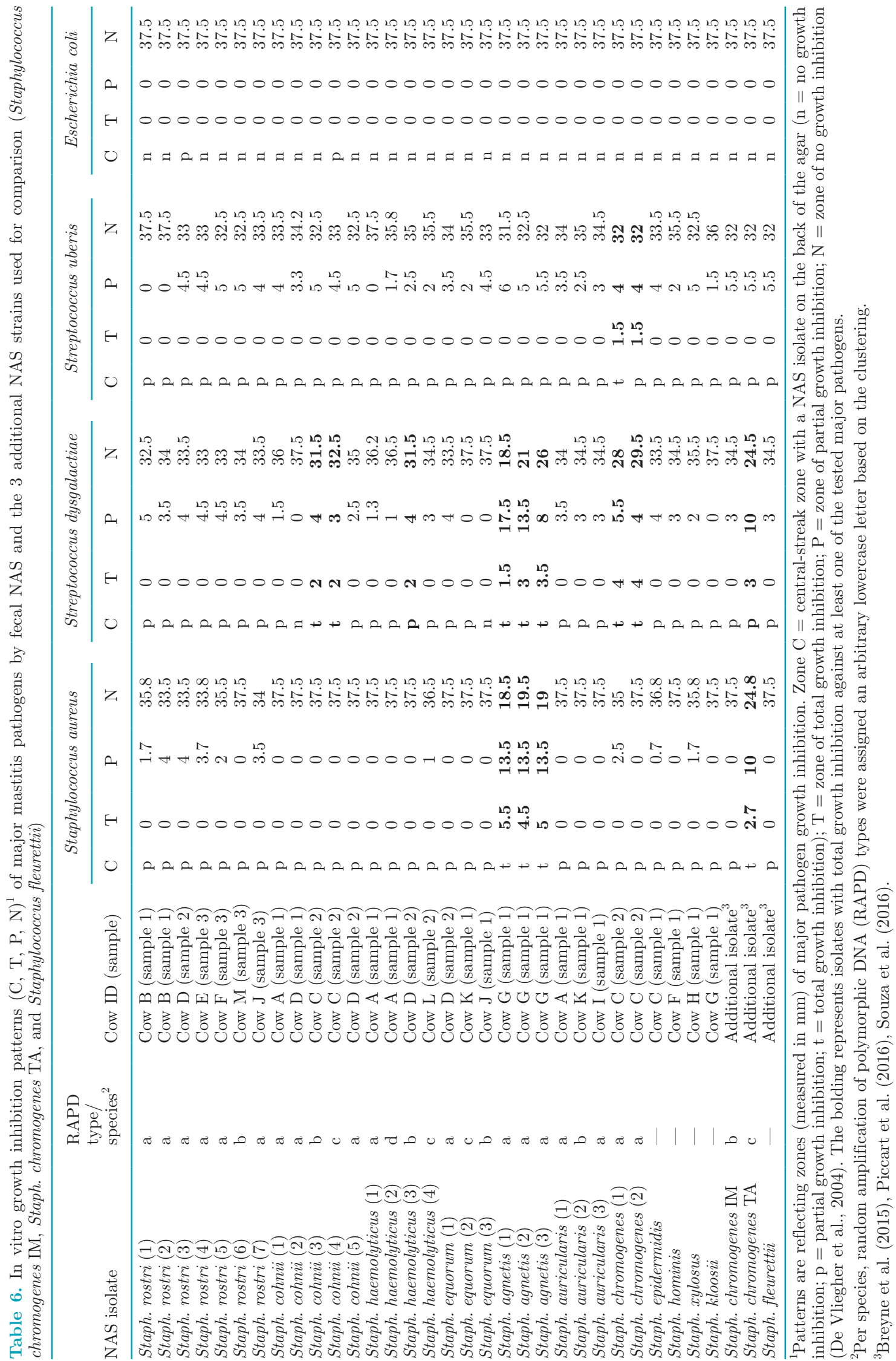



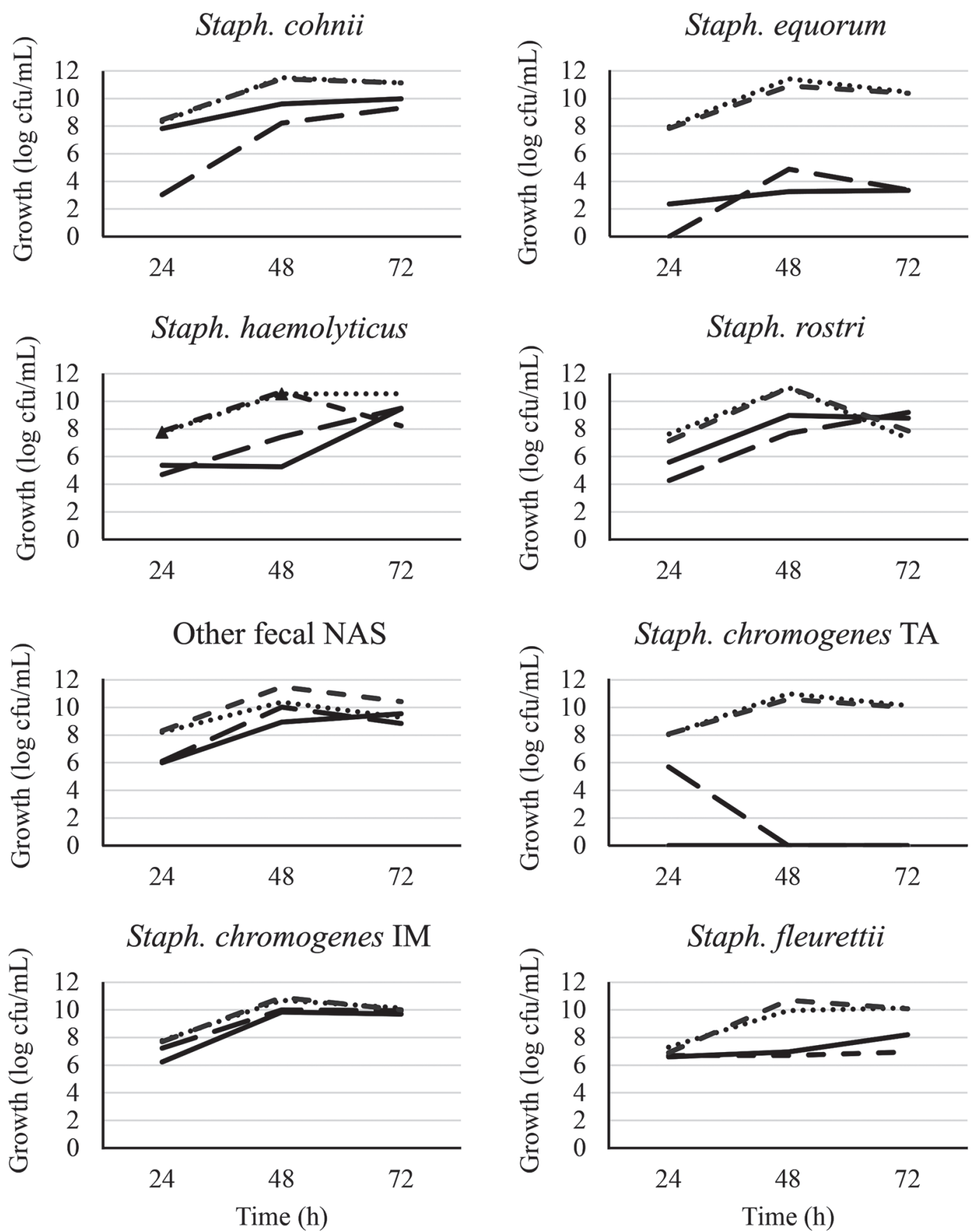

Figure 2. Overview of growth (log cfu/mL) over time (h) in different media: iron-rich/aerobic (dotted line), iron-rich/anaerobic (short-dash line), iron-deprived/aerobic (long-dash line), iron-deprived/anaerobic (solid line) of Staphylococcus cohnii, Staphylococcus equorum, Staphylococcus haemolyticus, Staphylococcus rostri, and other NAS with a fecal origin, and 3 additional isolates used for comparison (Staphylococcus chromogenes IM, Staph. chromogenes TA, and Staphylococcus fleurettii).

bination of different tests should be used to correctly categorize the sensitive or resistant NAS isolates (Hussain et al., 2000; Souza Antunes et al., 2007; John et al., 2009). However, the presence of resistance genes does not always correlate with phenotypic expression of antimicrobial resistance. Ten of the fecal NAS isolates belonging to 5 species (all isolated from the same farm) carried the blaZ gene without expressing phenotypic resistance, possibly due to mutations or gene silencing (Zscheck and Murray, 1993; Olsen et al., 2006). When the isolates tested resistant with the nitrocefin test or the cefoxitin/oxacillin disk diffusion test, but did not 
carry any of the tested resistance genes, containment of other genes than bla $Z$ or overproduction of $\beta$-lactamase might explain this finding (Chambers, 1997; Frey et al., 2013; Xu et al., 2014).

The majority of the fecal NAS isolates had the potential to form biofilms (84\%). Biofilm formation allows bacteria to survive in hostile environments, such as the cow's environment and the mammary gland, and also spread to colonize new habitats (Lee et al., 2014). Non-aureus staphylococci isolated from milk samples showed a similar (Tremblay et al., 2013) or even higher ability (up to 100\%) for biofilm production (Darwish and Asfour, 2013; da Costa Krewer et al., 2015; Felipe et al., 2017). Still, in contrast to the milk isolates from those studies, all except 1 fecal isolate were weak biofilm producers. However, the definition of weak, moderate, or strong in that respect differs somehow in every study, and caution is needed when comparing results. Actually, only 2 fecal NAS isolates harbored genes related to biofilm formation. One bap gene was found in Staph. xylosus, which is in accordance with Tremblay et al. (2013), who suggested that the biofilm formation mechanism in Staph. xylosus is bap dependent. The other bap gene was present in a Staph. equorum isolate. Other biofilm-associated genes should be tested to find the underlying mechanism.

Two Staph. cohnii isolates recovered from 2 fecal samples of the same cow belonged to the same strain according to the RAPD banding patterns, and both isolates showed a weak ability for biofilm production. It has been suggested that bap-positive Staph. aureus isolates are more likely to colonize and persist in the bovine mammary gland and are less susceptible to antimicrobial treatments (Cucarella et al., 2004). Investigating the correlation between persistent fecal shedding and biofilm production might be interesting.

Of the fecal isolates, $26 \%$ showed a phenotypic capability to totally inhibit the growth of Staph. aureus, Strep. dysgalactiae, Strep. uberis, or more than one of these species. These results are similar to those presented by Carson et al. (2017), who found that $21 \%$ of the NAS isolates originating from the bovine udder were potential bacteriocin producers. Partial growth inhibition at the center streak is found in all the fecal isolates against at least one of the tested pathogens. This finding could be partly explained by a reduced availability of nutrition as was confirmed by crossstreaking the isolates against themselves. None of the isolates with a fecal origin showed inhibitory activity against $E$. coli, a genus with low phylogenetic relation to Staphylococcus spp.

During an IMI, the growth conditions in the mammary gland change substantially. Mayer et al. (1988) reported a dramatic drop to less than $10 \%$ of the oxy- gen levels compared with milk from a healthy udder. Depending on the inflammation, the concentration of lactoferrin and transferrin, 2 proteins able to bind ferric iron, increases (Rainard et al., 1982). The NAS isolates originating from fecal samples displayed growth patterns resembling that of Staph. chromogenes IM, which we consider to be a true host-dependent strain. Based on this finding, we hypothesize that these fecal strains could grow in the mammary gland and cause an IMI, although this possibility needs to be studied. Substantiating the environmental nature of Staph. equorum as a species, isolates belonging to this species tended to show comparable growth characteristics as Staph. chromogenes TA, a strain that is associated with the teat apex.

This study, performed on 1 herd with a limited number of cows and NAS isolates, is the first to report on the presence of NAS in fecal samples of dairy cows. A larger field study conducted in more herds could combine fecal samples with teat apex samples and quarter milk samples collected at the same time. Strain typing will allow testing the potential link between NAS present in the different habitats and investigating the ability of fecal NAS to cause teat apex colonization, IMI, or both.

\section{CONCLUSIONS}

More than half of the cows from 1 herd were shedding NAS in rectal feces and up to 3 NAS species, belonging to 11 different species, were present per fecal sample. The predominant species were Staph. rostri, Staph. cohnii, and Staph. haemolyticus with all Staph. agnetis, Staph. chromogenes, and Staph. rostri isolates being similar according to the RAPD banding patterns. $\beta$-Lactamase production was present in all but 3 fecal isolates. Growth inhibition against Staph. aureus, Strep. uberis, Strep. dysgalactiae, or more than one of these species was found in 8 fecal isolates. The majority of fecal isolates showed the ability to form biofilms and were capable of growing in conditions mimicking the mammary environment.

\section{ACKNOWLEDGMENTS}

The authors thank Justine Huyghe (Department of Reproduction, Obstetrics, and Herd Health, Faculty of Veterinary Medicine, Ghent University, Merelbeke, Belgium) for her excellent help and assistance in preparing this paper, and Isabel Lemahieu (Department of Reproduction, Obstetrics, and Herd Health, Faculty of Veterinary Medicine, Ghent University, Merelbeke, Belgium) for the technical support. 


\section{REFERENCES}

Adegoke, A. A., and A. I. Okoh. 2014. Species diversity and antibiotic resistance properties of Staphylococcus of farm animal origin in Nkonkobe Municipality, South Africa. Folia Microbiol. (Praha) 59:133-140. https://doi.org/10.1007/s12223-013-0275-1.

Adkins, P. R. F., S. Dufour, J. N. Spain, M. J. Calcutt, T. J. Reilly, G. C. Stewart, and J. R. Middleton. 2018a. Cross-sectional study to identify staphylococcal species isolated from teat and inguinal skin of different-aged dairy heifers. J. Dairy Sci. 101:3213-3225. https: //doi.org/10.3168/jds.2017-13974.

Adkins, P. R. F., S. Dufour, J. N. Spain, M. J. Calcutt, T. J. Reilly, G. C. Stewart, and J. R. Middleton. 2018b. Molecular characterization of non-aureus Staphylococcus spp. from heifer intramammary infections and body sites. J. Dairy Sci. 101:5388-5403. https://doi .org/10.3168/jds.2017-13910.

Adkins, P. R. F., J. R. Middleton, M. J. Calcutt, G. C. Stewart, and L. K. Fox. 2017. Species identification and strain typing of Staphylococcus agnetis and Staphylococcus hyicus isolates from bovine milk by use of a novel multiplex PCR assay and pulsed-field gel electrophoresis. J. Clin. Microbiol. 55:1778-1788. https://doi.org/ 10.1128/Jcm.02239-16.

Baron, F., M. F. Cochet, W. Ablain, N. Grosset, M. N. Madec, F. Gonnet, S. Jan, and M. Gautier. 2006. Rapid and cost-effective method for microorganism enumeration based on miniaturization of the conventional plate-counting technique. Lait 86:251-257. https://doi.org/10.1051/lait:2006005.

Bauer, A. W., W. M. M. Kirby, J. C. Sherris, and M. Turck. 1966. Antibiotic susceptibility testing by a standardized single disk method. Am. J. Clin. Pathol. 45:493-496.

Bexiga, R., M. G. Rato, A. Lemsaddek, T. Semedo-Lemsaddek, C. Carneiro, H. Pereira, D. J. Mellor, K. A. Ellis, and C. L. Vilela. 2014. Dynamics of bovine intramammary infections due to coagulase-negative staphylococci on four farms. J. Dairy Res. 81:208214. https://doi.org/10.1017/s0022029914000041.

Braem, G., S. De Vliegher, B. Verbist, V. Piessens, E. Van Coillie, L. De Vuyst, and F. Leroy. 2013. Unraveling the microbiota of teat apices of clinically healthy lactating dairy cows, with special emphasis on coagulase-negative staphylococci. J. Dairy Sci. 96:1499-1510. https://doi.org/10.3168/jds.2012-5493.

Braem, G., B. Stijlemans, W. Van Haken, S. De Vliegher, L. De Vuyst, and F. Leroy. 2014. Antibacterial activities of coagulase-negative staphylococci from bovine teat apex skin and their inhibitory effect on mastitis-related pathogens. J. Appl. Microbiol. 116:10841093. https://doi.org/10.1111/jam.12447.

Breyne, K., S. De Vliegher, A. De Visscher, S. Piepers, and E. Meyer. 2015. Technical note: A pilot study using a mouse mastitis model to study differences between bovine associated coagulase-negative staphylococci. J. Dairy Sci. 98:1090-1100. https://doi.org/10 .3168/jds.2014-8699.

Carson, D. A., H. W. Barkema, S. Naushad, and J. De Buck. 2017. Bacteriocins of non-aureus staphylococci isolated from bovine milk. Appl. Environ. Microbiol. 83:e01015-e01017. https://doi .org/10.1128/AEM.01015-17.

Chambers, H. F. 1997. Methicillin resistance in staphylococci: Molecular and biochemical basis and clinical implications. Clin. Microbiol. Rev. 10:781-791.

Christensen, G. D., W. A. Simpson, J. J. Younger, L. M. Baddour, F. F. Barrett, D. M. Melton, and E. H. Beachey. 1985. Adherence of coagulase-negative staphylococci to plastic tissue culture plates: A quantitative model for the adherence of staphylococci to medical devices. J. Clin. Microbiol. 22:996-1006.

CLSI. 2018a. VET01 Performance standards for antimicrobial disk and dilution susceptibility tests for bacteria isolated from animals. 5th ed. Clinical and Laboratory Standards Institute, Wayne, PA.

CLSI. 2018b. VET08 Performance standards for antimicrobial disk and dilution susceptibility tests for bacteria isolated from animals. 4th ed. Clinical and Laboratory Standards Institute, Wayne, PA.

Condas, L. A. Z., J. De Buck, D. B. Nobrega, D. A. Carson, J. P. Roy, G. P. Keefe, T. J. DeVries, J. R. Middleton, S. Dufour, and H. W. Barkema. 2017. Distribution of non-aureus staphylococci species in udder quarters with low and high somatic cell count, and clinical mastitis. J. Dairy Sci. 100:5613-5627. https://doi.org/10.3168/jds .2016-12479.

Cucarella, C., M. A. Tormo, C. Ubeda, M. P. Trotonda, M. Monzon, C. Peris, B. Amorena, I. Lasa, and J. R. Penades. 2004. Role of biofilm-associated protein bap in the pathogenesis of bovine Staphylococcus aureus. Infect. Immun. 72:2177-2185. https://doi.org/10 .1128/IAI.72.4.2177-2185.2004.

da Costa Krewer, C., E. Santos Amanso, G. Veneroni Gouveia, R. de Lima Souza, M. M. da Costa, and R. Aparecido Mota. 2015. Resistance to antimicrobials and biofilm formation in Staphylococcus spp. isolated from bovine mastitis in the Northeast of Brazil. Trop. Anim. Health Prod. 47:511-518. https://doi.org/10.1007/ s11250-014-0752-9.

Darwish, S. F., and H. A. Asfour. 2013. Investigation of biofilm forming ability in staphylococci causing bovine mastitis using phenotypic and genotypic assays. ScientificWorldJournal 2013:378492 https://doi.org/10.1155/2013/378492.

De Visscher, A., F. Haesebrouck, S. Piepers, W. Vanderhaeghen, K. Supré, F. Leroy, E. Van Coillie, and S. De Vliegher. 2013. Assessment of the suitability of mannitol salt agar for growing bovineassociated coagulase-negative staphylococci and its use under field conditions. Res. Vet. Sci. 95:347-351. https://doi.org/10.1016/j .rvsc.2013.05.015.

De Visscher, A., S. Piepers, F. Haesebrouck, and S. De Vliegher. 2016a. Intramammary infection with coagulase-negative staphylococci at parturition: Species-specific prevalence, risk factors, and effect on udder health. J. Dairy Sci. 99:6457-6469. https://doi .org/10.3168/jds.2015-10458.

De Visscher, A., S. Piepers, F. Haesebrouck, and S. De Vliegher. 2016b. Teat apex colonization with coagulase-negative Staphylococcus species before parturition: Distribution and species-specific risk factors. J. Dairy Sci. 99:1427-1439. https://doi.org/10.3168/ jds.2015-10326.

De Visscher, A., S. Piepers, F. Haesebrouck, K. Supre, and S. De Vliegher. 2017. Coagulase-negative Staphylococcus species in bulk milk: Prevalence, distribution, and associated subgroup- and species-specific risk factors. J. Dairy Sci. 100:629-642. https://doi .org/10.3168/jds.2016-11476.

De Visscher, A., K. Supre, F. Haesebrouck, R. N. Zadoks, V. Piessens, E. Van Coillie, S. Piepers, and S. De Vliegher. 2014. Further evidence for the existence of environmental and host-associated species of coagulase-negative staphylococci in dairy cattle. Vet. Microbiol. 172:466-474. https://doi.org/10.1016/j.vetmic.2014.06 .011 .

De Vliegher, S., G. Opsomer, A. Vanrolleghem, L. A. Devriese, O. C. Sampimon, J. Sol, H. W. Barkema, F. Haesebrouck, and A. de Kruif. 2004. In vitro growth inhibition of major mastitis pathogens by Staphylococcus chromogenes originating from teat apices of dairy heifers. Vet. Microbiol. 101:215-221. https://doi.org/10 .1016/j.vetmic.2004.03.020.

Eastick, K., J. P. Leeming, D. Bennett, and M. R. Millar. 1996. Reservoirs of coagulase negative staphylococci in preterm infants. Arch. Dis. Child Fetal Neonatal Ed. 74:F99-F104. https://doi.org/10 .1136/fn.74.2.F99.

Felipe, V., C. A. Morgante, P. S. Somale, F. Varroni, M. L. Zingaretti, R. A. Bachetti, S. G. Correa, and C. Porporatto. 2017. Evaluation of the biofilm forming ability and its associated genes in Staphylococcus species isolates from bovine mastitis in Argentinean dairy farms. Microb. Pathog. 104:278-286. https://doi.org/10.1016/j .micpath.2017.01.047.

Frey, Y., J. P. Rodriguez, A. Thomann, S. Schwendener, and V. Perreten. 2013. Genetic characterization of antimicrobial resistance in coagulase-negative staphylococci from bovine mastitis milk. J. Dairy Sci. 96:2247-2257. https://doi.org/10.3168/jds.2012-6091.

Fry, P. R., J. R. Middleton, S. Dufour, J. Perry, D. Scholl, and I. Dohoo. 2014. Association of coagulase-negative staphylococcal species, mammary quarter milk somatic cell count, and persistence of intramammary infection in dairy cattle. J. Dairy Sci. 97:48764885. https://doi.org/10.3168/jds.2013-7657. 
García-Álvarez, L., M. T. Holden, H. Lindsay, C. R. Webb, D. F. Brown, M. D. Curran, E. Walpole, K. Brooks, D. J. Pickard, C. Teale, J. Parkhill, S. D. Bentley, G. F. Edwards, E. K. Girvan, A. M. Kearns, B. Pichon, R. L. Hill, A. R. Larsen, R. L. Skov, S. J. Peacock, D. J. Maskell, and M. A. Holmes. 2011. Meticillinresistant Staphylococcus aureus with a novel mecA homologue in human and bovine populations in the UK and Denmark: A descriptive study. Lancet Infect. Dis. 11:595-603. https://doi.org/10 .1016/S1473-3099(11)70126-8

Haveri, M., S. Suominen, L. Rantala, T. Honkanen-Buzalski, and S. Pyorala. 2005. Comparison of phenotypic and genotypic detection of penicillin G resistance of Staphylococcus aureus isolated from bovine intramammary infection. Vet. Microbiol. 106:97-102. https: //doi.org/10.1016/j.vetmic.2004.12.015.

Hogan, J. S., R. N. Gonzalez, R. J. Harmon, S. C. Nickerson, S. P. Oliver, J. W. Pankey, and K. L. Smith. 1999. Laboratory Handbook on Bovine Mastitis. 2nd ed. National Mastitis Council, Madison, WI.

Hussain, Z., L. Stoakes, V. Massey, D. Diagre, V. Fitzgerald, S. El Sayed, and R. Lannigan. 2000. Correlation of oxacillin MIC with $m e c A$ gene carriage in coagulase-negative staphylococci. J. Clin. Microbiol. 38:752-754

John, M. A., J. Burden, J. I. Stuart, R. C. Reyes, R. Lannigan, S. Milburn, D. Diagre, B. Wilson, and Z. Hussain. 2009. Comparison of three phenotypic techniques for detection of methicillin resistance in Staphylococcus spp. reveals a species-dependent performance. J. Antimicrob. Chemother. 63:493-496. https://doi.org/10.1093/ $\mathrm{jac} / \mathrm{dkn} 527$.

Jørgensen, H. J., A. B. Nordstoga, S. Sviland, R. N. Zadoks, L. Solverod, B. Kvitle, and T. Mork. 2016. Streptococcus agalactiae in the environment of bovine dairy herds-Rewriting the textbooks? Vet. Microbiol. 184:64-72. https://doi.org/10.1016/j.vetmic.2015 .12 .014

Komine, K., Y. Komine, T. Kuroishi, J. Kobayashi, Y. Obara, and K. Kumagai. 2005. Small molecule lactoferrin with an inflammatory effect but no apparent antibacterial activity in mastitic mammary gland secretion. J. Vet. Med. Sci. 67:667-677. https://doi.org/10 $.1292 /$ jvms.67.667.

Kot, B., M. Piechota, K. M. Wolska, A. Frankowska, E. Zdunek, T. Binek, E. Klopotowska, and M. Antosiewicz. 2012. Phenotypic and genotypic antimicrobial resistance of staphylococci from bovine milk. Pol. J. Vet. Sci. 15:677-683. https://doi.org/10.2478/v10181 -012-0105-4.

Le Maréchal, C., G. Jan, S. Even, J. A. McCulloch, V. Azevedo, R. Thiéry, E. Vautor, and Y. Le Loir. 2009. Development of serological proteome analysis of mastitis by Staphylococcus aureus in ewes. J. Microbiol. Methods 79:131-136. https://doi.org/10.1016/ j.mimet.2009.08.017.

Lee, S. H., B. L. Mangolin, J. L. Goncalves, D. V. Neeff, M. P. Silva, A. G. Cruz, and C. A. Oliveira. 2014. Biofilm-producing ability of Staphylococcus aureus isolates from Brazilian dairy farms. J. Dairy Sci. 97:1812-1816. https://doi.org/10.3168/jds.2013-7387.

Leonard, F. C., and B. K. Markey. 2008. Meticillin-resistant Staphylococcus aureus in animals: A review. Vet. J. 175:27-36. https://doi .org/10.1016/j.tvjl.2006.11.008

Locatelli, C., S. Piepers, S. De Vliegher, A. Barberio, K. Supre, L. Scaccabarozzi, G. Pisoni, V. Bronzo, F. Haesebrouck, and P. Moroni. 2013. Effect on quarter milk somatic cell count and antimicrobial susceptibility of Staphylococcus rostri causing intramammary infection in dairy water buffaloes. J. Dairy Sci. 96:3799-3805. https://doi.org/10.3168/jds.2012-6275.

Mayer, S. J., A. E. Waterman, P. M. Keen, N. Craven, and F. J. Bourne. 1988. Oxygen concentration in milk of healthy and mastitic cows and implications of low oxygen tension for the killing of Staphylococcus aureus by bovine neutrophils. J. Dairy Res. 55:513519. https://doi.org/10.1017/S0022029900033288.

Messier, S., R. Higgins, Y. Couture, and M. Morin. 1984. Comparison of swabbing and biopsy for studying the flora of the bovine uterus. Can. Vet. J. 25:283-288.

Mørk, T., H. J. Jørgensen, M. Sunde, B. Kvitle, S. Sviland, S. Waage, and T. Tollersrud. 2012. Persistence of staphylococcal species and genotypes in the bovine udder. Vet. Microbiol. 159:171-180. https: //doi.org/10.1016/j.vetmic.2012.03.034.

Munoz, M. A., C. Ahlstrom, B. J. Rauch, and R. N. Zadoks. 2006. Fecal shedding of Klebsiella pneumoniae by dairy cows. J. Dairy Sci. 89:3425-3430. https://doi.org/10.3168/jds.S0022-0302(06)72379 $-7$.

Murakami, K., W. Minamide, K. Wada, E. Nakamura, H. Teraoka and S. Watanabe. 1991. Identification of methicillin-resistant strains of staphylococci by polymerase chain reaction. J. Clin. Microbiol. 29:2240-2244.

Nobrega, D. B., S. Naushad, S. A. Naqvi, L. A. Z. Condas, V. Saini, J. P. Kastelic, C. Luby, J. De Buck, and H. W. Barkema. 2018. Prevalence and genetic basis of antimicrobial resistance in nonaureus staphylococci isolated from Canadian dairy herds. Front. Microbiol. 9:256. https://doi.org/10.3389/fmicb.2018.00256.

Ntuli, V., P. M. Njage, and E. M. Buys. 2016. Characterization of Escherichia coli and other Enterobacteriaceae in producer-distributor bulk milk. J. Dairy Sci. 99:9534-9549. https://doi.org/10 .3168/jds.2016-11403.

Olsen, J. E., H. Christensen, and F. M. Aarestrup. 2006. Diversity and evolution of blaZ from Staphylococcus aureus and coagulase-negative staphylococci. J. Antimicrob. Chemother. 57:450-460. https:/ /doi.org/10.1093/jac/dki492.

Piccart, K., J. Verbeke, A. De Visscher, S. Piepers, F. Haesebrouck, and S. De Vliegher. 2016. Local host response following an intramammary challenge with Staphylococcus fleurettii and different strains of Staphylococcus chromogenes in dairy heifers. Vet. Res. 47:56. https://doi.org/10.1186/s13567-016-0338-9.

Piepers, S., L. De Meulemeester, A. de Kruif, G. Opsomer, H. W. Barkema, and S. De Vliegher. 2007. Prevalence and distribution of mastitis pathogens in subclinically infected dairy cows in Flanders, Belgium. J. Dairy Res. 74:478-483. https://doi.org/10.1017/ S0022029907002841.

Piessens, V., S. De Vliegher, B. Verbist, G. Braem, A. Van Nuffel, L. De Vuyst, M. Heyndrickx, and E. Van Coillie. 2012a. Characterization of coagulase-negative Staphylococcus species from cows' milk and environment based on bap, icaA, and mecA genes and phenotypic susceptibility to antimicrobials and teat dips. J. Dairy Sci 95:7027-7038. https://doi.org/10.3168/jds.2012-5400.

Piessens, V., S. De Vliegher, B. Verbist, G. Braem, A. Van Nuffel, L. De Vuyst, M. Heyndrickx, and E. Van Coillie. 2012b. Intra-species diversity and epidemiology varies among coagulase-negative Staphylococcus species causing bovine intramammary infections. Vet. Microbiol. 155:62-71. https://doi.org/10.1016/j.vetmic.2011 .08 .005 .

Piessens, V., E. Van Coillie, B. Verbist, K. Supré, G. Braem, A. Van Nuffel, L. De Vuyst, M. Heyndrickx, and S. De Vliegher. 2011. Distribution of coagulase-negative Staphylococcus species from milk and environment of dairy cows differs between herds. J. Dairy Sci. 94:2933-2944. https://doi.org/10.3168/jds.2010-3956.

Pitkälä, A., M. Haveri, S. Pyörälä, V. Myllys, and T. Honkanen-Buzalski. 2004. Bovine mastitis in Finland 2001-Prevalence, distribution of bacteria, and antimicrobial resistance. J. Dairy Sci 87:2433-2441. https://doi.org/10.3168/jds.S0022-0302(04)73366 -4 .

Rainard, P., B. Poutrel, and J. P. Caffin. 1982. Lactoferrin and transferrin in bovine milk in relation to certain physiological and pathological factors. Ann. Rech. Vet. 13:321-328.

Rohde, H., E. C. Burandt, N. Siemssen, L. Frommelt, C. Burdelski, S. Wurster, S. Scherpe, A. P. Davies, L. G. Harris, M. A. Horstkotte, J. K. Knobloch, C. Ragunath, J. B. Kaplan, and D. Mack. 2007. Polysaccharide intercellular adhesin or protein factors in biofilm accumulation of Staphylococcus epidermidis and Staphylococcus aureus isolated from prosthetic hip and knee joint infections. Biomaterials 28:1711-1720. https://doi.org/10.1016/j.biomaterials .2006.11.046.

Rohde, H., C. Burdelski, K. Bartscht, M. Hussain, F. Buck, M. A Horstkotte, J. K. Knobloch, C. Heilmann, M. Herrmann, and D. Mack. 2005. Induction of Staphylococcus epidermidis biofilm formation via proteolytic processing of the accumulation-associated 
protein by staphylococcal and host proteases. Mol. Microbiol. 55:1883-1895. https://doi.org/10.1111/j.1365-2958.2005.04515.x.

Ruusunen, M., M. Salonen, H. Pulkkinen, M. Huuskonen, S. Hellstrom, J. Revez, M. L. Hanninen, M. Fredriksson-Ahomaa, and M. Lindstrom. 2013. Pathogenic bacteria in Finnish bulk tank milk. Foodborne Pathog. Dis. 10:99-106. https://doi.org/10.1089/fpd .2012 .1284 .

Sampimon, O. C., T. J. Lam, D. J. Mevius, Y. H. Schukken, and R. N. Zadoks. 2011. Antimicrobial susceptibility of coagulase-negative staphylococci isolated from bovine milk samples. Vet. Microbiol. 150:173-179. https://doi.org/10.1016/j.vetmic.2011.01.017.

Schukken, Y. H., R. N. Gonzalez, L. L. Tikofsky, H. F. Schulte, C. G. Santisteban, F. L. Welcome, G. J. Bennett, M. J. Zurakowski, and R. N. Zadoks. 2009. CNS mastitis: Nothing to worry about? Vet. Microbiol. 134:9-14. https://doi.org/10.1016/j.vetmic.2008 .09.014.

Slaughter, D. M., T. G. Patton, G. Sievert, R. J. Sobieski, and S. S. Crupper. 2001. Antibiotic resistance in coagulase-negative staphylococci isolated from Cope's gray treefrogs (Hyla chrysoscelis). FEMS Microbiol. Lett. 205:265-270. https://doi.org/0.1111/j .1574-6968.2001.tb10959.x.

Smith, D., M. Blackford, S. Younts, R. Moxley, J. Gray, L. Hungerford, T. Milton, and T. Klopfenstein. 2001. Ecological relationships between the prevalence of cattle shedding Escherichia coli O157: H7 and characteristics of the cattle or conditions of the feedlot pen. J. Food Prot. 64:1899-1903. https://doi.org/10.4315/ 0362-028x-64.12.1899.

Souza, F. N., S. Piepers, A. M. Della Libera, M. B. Heinemann, M. M. Cerqueira, and S. De Vliegher. 2016. Interaction between bovineassociated coagulase-negative staphylococci species and strains and bovine mammary epithelial cells reflects differences in ecology and epidemiological behavior. J. Dairy Sci. 99:2867-2874. https:// doi.org/10.3168/jds.2015-10230.

Souza Antunes, A. L., C. Secchi, K. C. Reiter, L. R. Rodrigues Perez, A. L. Peixoto de Freitas, and P. Alves d'Azevedo. 2007. Evaluation of oxacillin and cefoxitin disks for detection of resistance in coagulase negative staphylococci. Mem. Inst. Oswaldo Cruz 102:719-723.

Stevens, M., S. Piepers, K. Supre, and S. De Vliegher. 2018. Antimicrobial consumption on dairy herds and its association with antimicrobial inhibition zone diameters of non-aureus staphylococci and Staphylococcus aureus isolated from subclinical mastitis. J. Dairy Sci. 101:3311-3322. https://doi.org/10.3168/jds.2017-13365.

Supré, K., S. De Vliegher, O. C. Sampimon, R. N. Zadoks, M. Vaneechoutte, M. Baele, E. De Graef, S. Piepers, and F. Haesebrouck. 2009. Technical note: Use of transfer RNA-intergenic spacer PCR combined with capillary electrophoresis to identify coagulase-negative Staphylococcus species originating from bovine milk and teat apices. J. Dairy Sci. 92:3204-3210. https://doi.org/ $10.3168 /$ jds.2008-1923.
Supré, K., F. Haesebrouck, R. N. Zadoks, M. Vaneechoutte, S. Piepers, and S. De Vliegher. 2011. Some coagulase-negative Staphylococcus species affect udder health more than others. J. Dairy Sci. 94:2329-2340. https://doi.org/10.3168/jds.2010-3741.

Taponen, S., and S. Pyörälä. 2009. Coagulase-negative staphylococci as cause of bovine mastitis - Not so different from Staphylococcus aureus? Vet. Microbiol. 134:29-36. https://doi.org/10.1016/j .vetmic.2008.09.011.

Tremblay, Y. D., D. Lamarche, P. Chever, D. Haine, S. Messier, and M. Jacques. 2013. Characterization of the ability of coagulasenegative staphylococci isolated from the milk of Canadian farms to form biofilms. J. Dairy Sci. 96:234-246. https://doi.org/10.3168/ jds.2012-5795.

Unal, S., J. Hoskins, J. E. Flokowitsch, C. Y. Wu, D. A. Preston, and P. L. Skatrud. 1992. Detection of methicillin-resistant staphylococci by using the polymerase chain reaction. J. Clin. Microbiol. 30:1685-1691.

Vanderhaeghen, W., S. Piepers, F. Leroy, E. Van Coillie, F. Haesebrouck, and S. De Vliegher. 2014. Invited review: Effect, persistence, and virulence of coagulase-negative Staphylococcus species associated with ruminant udder health. J. Dairy Sci. 97:5275-5293. https://doi.org/10.3168/jds.2013-7775.

Vanderhaeghen, W., S. Piepers, F. Leroy, E. Van Coillie, F. Haesebrouck, and S. De Vliegher. 2015. Identification, typing, ecology and epidemiology of coagulase negative staphylococci associated with ruminants. Vet. J. 203:44-51. https://doi.org/10.1016/j.tvjl .2014.11.001.

Verbist, B., V. Piessens, A. Van Nuffel, L. De Vuyst, M. Heyndrickx, L. Herman, E. Van Coillie, and S. De Vliegher. 2011. Sources other than unused sawdust can introduce Klebsiella pneumoniae into dairy herds. J. Dairy Sci. 94:2832-2839. https://doi.org/10.3168/ jds.2010-3700.

Vitali, L. A., D. Petrelli, A. Lamikanra, M. Prenna, and E. O. Akinkunmi. 2014. Diversity of antibiotic resistance genes and staphylococcal cassette chromosome mec elements in faecal isolates of coagulase-negative staphylococci from Nigeria. BMC Microbiol. 14:106 https://doi.org/10.1186/1471-2180-14-106.

Waller, K. P., A. Aspan, A. Nyman, Y. Persson, and U. G. Andersson. 2011. CNS species and antimicrobial resistance in clinical and subclinical bovine mastitis. Vet. Microbiol. 152:112-116. https:// doi.org/10.1016/j.vetmic.2011.04.006.

Xu, J., C. Shi, M. Song, X. Xu, P. Yang, G. Paoli, and X. Shi. 2014. Phenotypic and genotypic antimicrobial resistance traits of foodborne Staphylococcus aureus isolates from Shanghai. J. Food Sci. 79:M635-M642. https://doi.org/10.1111/1750-3841.12405.

Zscheck, K. K., and B. E. Murray. 1993. Genes involved in the regulation of beta-lactamase production in enterococci and staphylococci. Antimicrob. Agents Chemother. 37:1966-1970. 